\title{
Shark predation and tooth wear in a population of northeastern Pacific killer whales
}

\author{
John K. B. Ford ${ }^{1, *}$, Graeme M. Ellis ${ }^{1}$, Craig O. Matkin ${ }^{2}$, Michael H. Wetklo ${ }^{1}$, \\ Lance G. Barrett-Lennard ${ }^{3}$, Ruth E. Withler ${ }^{1}$ \\ ${ }^{1}$ Fisheries and Oceans Canada, Pacific Biological Station, Nanaimo, British Columbia V9T 6N7, Canada \\ ${ }^{2}$ North Gulf Oceanic Society, Homer, Alaska 99603, USA \\ ${ }^{3}$ Vancouver Aquarium, Vancouver, British Columbia V6G 3E2, Canada
}

\begin{abstract}
The cosmopolitan killer whale Orcinus orca feeds on a wide variety of prey types over its global range, but in at least some regions, genetically distinct and ecologically specialised lineages of killer whales coexist sympatrically. In coastal waters of the northeastern Pacific, 2 such lineages have been well described: the so-called 'residents' prey on teleost fish, especially salmonids and the other ('transients') on marine mammals. A third lineage in this region ('offshores') appears from chemical tracers to be ecologically distinct from residents and transients, but its diet is very poorly known. Here we describe 2 encounters with offshore killer whales during which multiple predation events involving sharks were observed. Using DNA analysis of tissue samples collected from these predation events, we identified the prey species as Pacific sleeper shark Somniosus pacificus and determined that a minimum of 16 individuals were consumed over the 2 encounters. This represents the first confirmed prey species of offshore killer whales based on field observations of foraging and the first record of any Somniosus species in the prey of Orcinus. We also show quantitatively that apical tooth wear is far greater in offshores than in resident and transient killer whales, and propose that such wear is at least in part due to abrasion from dermal denticles embedded in shark skin. Further studies are needed to determine whether offshore killer whales are as specialised ecologically as resident and transient killer whales, and whether sharks play a dominant role in their diet.
\end{abstract}

KEY WORDS: Ecological specialisation · Foraging strategy $\cdot$ Elasmobranch predation · Orcinus orca

\section{INTRODUCTION}

There is growing evidence that ecological adaptation and divergence is an important factor promoting reproductive isolation and speciation in a wide variety of taxa (Schluter 2001, Funk et al. 2006). Killer whales Orcinus orca, the oceans' apex predators, present an interesting case in which ecological specialisation has been associated with the divergence of the species into genetically distinct lineages that maintain social and reproductive isolation even in sympatry (Bigg 1982, Barrett-Lennard 2000, Ford et al. 2000, Pitman \& Ensor 2003, Foote et al. 2009, Morin et al. 2010). Some have suggested that such genetically and ecologically distinct lineages may be incipient (e.g. Baird et al. 1992) or separate (e.g. LeDuc et al. 2008, Morin et al. 2010) species.

As the most cosmopolitan of cetaceans, killer whales occur in all marine regions, from high-latitude Arctic and Antarctic waters to the tropics. The species has been documented to feed on more than 140 prey species, including marine mammals (cetaceans, pinnipeds, mustelids, sirenians), birds, turtles, fish (teleosts, elasmobranchs), and invertebrates (cephalopods, tunicates) (Ford 2009). However, culturally-determined foraging specialisations may constrain the diet breadth of lineages to a much narrower range of prey species. The most studied killer whales inhabit temperate coastal waters of the northeastern Pacific, where research on life history, social organisation, behaviour and foraging 
ecology has been conducted for over 3 decades. Field studies in waters around Vancouver Island, British Columbia (Canada), during the 1970s revealed the existence of 2 sympatric forms that differed in morphology, behaviour and movement patterns (Bigg et al. 1976, Bigg 1982, Bigg et al. 1990). Termed 'residents' and 'transients' based on their apparent fidelity to the study area, they are now known to be reproductively isolated and genetically distinct lineages (Stevens et al. 1989, Hoelzel \& Dover 1991, Barrett-Lennard 2000) that differ markedly in social dynamics (Ford \& Ellis 1999, Baird \& Whitehead 2000), vocal behaviour (Ford \& Fisher 1982, Barrett-Lennard et al. 1996, Deecke et al. 2005) and foraging strategy. Resident killer whales feed exclusively on teleost fish and squid, especially Pacific salmon Oncorhynchus spp. (Ford et al. 1998, Saulitis et al. 2000, Ford \& Ellis 2006), whereas transient killer whales prey on marine mammals and seabirds, but not fish (Ford et al. 1998, Saulitis et al. 2000). Sympatric populations of residents and transients have been documented in coastal waters of the northeastern Pacific from central California to the Aleutian Islands (Black et al. 1997, Ford \& Ellis 1999, Ford et al. 2000, Matkin \& Saulitis 1994, Matkin et al. 2007).

Since the late 1980s, a third sympatric form of killer whale has been observed in the range of resident and transient killer whales. Termed 'offshore' killer whales due to their tendency to be found in outer continental shelf waters, these whales have dorsal fins that are subtly different in shape from those of residents and transients and appear somewhat smaller in body size (Ford et al. 1992, 2000, Dahlheim et al. 2008). They have been found to be genetically distinct from both residents and transients, although they are in the same mitochondrial clade as residents (Barrett-Lennard 2000, Hoelzel et al. 2002, Morin et al. 2010). Almost 300 individuals have been photographically identified from 86 encounters with offshore killer whales in British Columbia waters during 1988 to 2008 (COSEWIC 2008). Individual photo-identification matches show extensive movements of whales throughout outer coast waters from southern California to the eastern Aleutian Islands, Alaska (Black et al. 1997, Ford et al. 2000, Dahlheim et al. 2008). Offshores have not been seen to mix with either resident or transient killer whale groups (Ford et al. 2000, Dahlheim et al. 2008).

The diet of offshore killer whales is very poorly known, but there is evidence that they may belong to an ecotype with a foraging specialisation distinct from that of resident and transient killer whales. Herman et al. (2005) examined fatty acid profiles, stable isotope ratios and organic pollutant concentrations using blubber biopsy samples from offshore killer whales and concluded that a piscivorous diet was probable, but that predation on marine mammals could not be ruled out. Similar analyses with a larger sample size led Krahn et al. (2007) to infer that the diet of offshore killer whales is distinct from that of residents and transients, and likely consists of high trophic level marine fishes.

Aspects of the behaviour and acoustics of offshore killer whales provide further evidence that they do not routinely hunt marine mammals. They often travel in large groups of 50 or more individuals, and disperse widely in a manner similar to that of piscivorous resident killer whales (Ford et al. 2000). As with similar sized aggregations of residents, groups of offshore killer whales tend to be highly vocal, producing a wide variety of pulsed calls and intense echolocation clicks (Ford et al. 1992, 2000). In contrast, mammal-eating transient killer whales typically forage and travel in small groups and in near silence, as part of a hunting strategy based on stealth (Barrett-Lennard et al. 1996, Deecke et al. 2005). Offshore killer whales appear indifferent to the presence of potential marine mammal prey in their vicinity, and marine mammals generally do not react to their presence, implying that the whales do not represent a predatory threat to them (Dahlheim et al. 2008; J. Ford, G. Ellis, C. Matkin unpubl. data).

Information on prey species consumed by offshore killer whales is scarce. Jones (2006) reported an observation in British Columbia of an offshore killer whale feeding on what appeared to be a Pacific halibut Hippoglossus stenolepis, although species identification could not be confirmed. Dahlheim et al. (2008) observed offshore whales interacting with Chinook salmon Oncorhynchus tshawytscha and blue sharks Prionace glauca off central California (USA), but actual feeding was not seen. Prey remains identified from the stomachs of offshore killer whales provide direct evidence of consumption. Heise et al. (2003) described the stomach contents of 2 offshore killer whales, a female and male, found stranded in semi-tidal Barnes Lake, southeast Alaska (USA). The stomach of the female contained salmonid bones, and that of the male contained bones of sculpin (family Cottidae) as well as some pieces of crab shell and eelgrass. As these whales had been entrapped within the lake for 6 to $10 \mathrm{wk}$ prior to death (Heise et al. 2003), these remains may not reflect normal feeding behaviour. The stomach of a female killer whale harpooned off the central California coast in 1964 and subsequently determined from DNA analysis to be an offshore (Rice 1968, Morin et al. 2006) contained remains of 2 opah Lampris guttatus and 2 sharks, either blue shark or whitetip shark Carcharhinus longimanus. It is noteworthy that this specimen, as well as another killer whale captured off southern California in 1961 and later determined to be from the offshore lineage (Morin et al. 2006), 
had extensive apical tooth wear (Caldwell \& Brown 1964). This was also true of the 2 stranded whales at Barnes Lake (Bain 1995, D. Bain pers. comm.). Dahlheim et al. (2008) noted a lack of substantial tooth wear in several transient killer whale skulls examined qualitatively.

In this paper, we describe 2 encounters with offshore killer whales in British Columbia and Alaska that involved multiple predation events from which we were able to collect tissue samples for prey identification. We used DNA sequence analysis of the mitochondrial 16S and cytochrome $b$ (cytb) genes for prey species identification. Both genes have been applied previously to marine species identification (Greig et al. 2005, Blanco et al. 2008, Tollit et al. 2009). We conducted sequence analysis of the hypervariable mitochondrial control region (CR), often applied in shark population structure analysis (Keeney et al. 2003, Ramírez-Macías et al. 2007), to determine the number of haplotypes present among the prey tissue samples. We also present a comparative analysis of tooth wear in resident, transient and offshore killer whales, which provides further evidence that unusual and severe apical tooth wear is typical in offshores but not in the other types. We propose that sharks are important in the foraging ecology of offshore killer whales and that abrasion resulting from dermal denticles found in the skin of sharks may be at least partly responsible for such extreme tooth wear.

\section{MATERIALS AND METHODS}

Field data collection. Offshore killer whales were encountered on 98 occasions in coastal waters $(<50 \mathrm{~km}$ from land) between southern British Columbia and Prince William Sound, Alaska ( 49 to $\sim 60^{\circ} \mathrm{N}$ latitude) during 1988 to 2009. A variety of research vessels were used for data collection, ranging from 5 to $20 \mathrm{~m}$ in length. Whales were photographed for individual identification using $35 \mathrm{~mm}$ film or digital SLR cameras with 200 to $300 \mathrm{~mm}$ lenses. Individuals were identified from natural markings as described by Ford et al. (2000) using reference catalogues compiled by the Cetacean Research Program, Pacific Biological Station (Fisheries \& Oceans Canada, Nanaimo, BC).

During encounters with offshore killer whales, a close watch was maintained for evidence of foraging and successful feeding, such as sudden changes in swimming direction and speed, high arching dives and circling. Sites of suspected predation were approached once whales had moved on, and any prey remains visible at the surface or in the water column were collected using a fine mesh dip net with a $4 \mathrm{~m}$ telescoping handle (for further details, see Ford \& Ellis 2006). Prey remains were placed in $20 \mathrm{ml}$ vials containing 95\% ethanol for preservation. Vessel tracks and positions of predation events were recorded by GPS.

Genetic identification of prey samples. Total DNA was extracted from 20 prey tissues and 2 eastern Pacific shark species (spiny dogfish Squalus acanthias and bluntnose sixgill shark Hexanchus griseus) using the DNeasy 96 Blood and Tissue Kit (Qiagen) following the manufacturer's protocol. DNA was eluted with 200 $\mu \mathrm{l}$ of Buffer AE, and 1.0 to $1.5 \mu \mathrm{l}$ was used as template in $25 \mu \mathrm{l}$ PCR reactions.

For species identification, a 261 basepair (bp) portion of the mitochondrial 16S gene was amplified with 16SF1 (GGACGAGAAGACCCT; Deagle et al. 2005) and 16SallR (CGCTGTTATCCCTAGGGTAACT) primers (Tollit et al. 2009). The PCR thermal profile was as per Tollit et al. (2009), with the number of cycles increased to 35 . PCR reactions contained $1 \times \mathrm{PCR}$ buffer, $0.5 \mathrm{mM} \mathrm{MgCl}_{2}, 0.3 \mathrm{mM}$ dNTPs, $2.5 \mu \mathrm{g}$ of bovine serum albumin (BSA), $0.5 \mu \mathrm{M}$ of each primer, and 0.625 units of Qiagen HotStar Taq polymerase. The mitochondrial cytb gene was also amplified to validate the species assignment of 2 prey tissues whose haplotypes had not been previously observed. Somniosus spp.-specific primers, Somn-GLU-L1 and Somn-CYTBH2 (Murray et al. 2008), were used to amplify the 869 bp cytb products. The thermal profile for PCR was as per Murray et al. (2008), with the initial $95^{\circ} \mathrm{C}$ denaturation reduced to $3 \mathrm{~min}$. Cytb $\mathrm{PCR}$ reactions contained $1 \times$ PCR buffer, $0.84 \mathrm{mM}$ dNTPs, $0.5 \mu \mathrm{M}$ of each primer and 1 unit of Qiagen Taq polymerase.

For CR haplotype analysis, we designed conserved primers from sequences for 7 shark species obtained from GenBank and aligned in MEGA4 (Tamura et al. 2007). A $941 \mathrm{bp}$ contiguous sequence of the CR was produced from the amplification of 2 PCR products: a 498 bp product amplified with SacaEx 3F (CCACATACCCTAATATACCAC) and SacaIn 2R (TAGTTATTGCTTCATWCCG) and a 640 bp product amplified with SacaIn 6F (GTGTACGGTTTGTGGWAC) and SacaEx 7R (AGTATACAKTCGGCCCTCG). PCR conditions were $3 \mathrm{~min}$ at $95^{\circ} \mathrm{C}, 40$ cycles of $94^{\circ} \mathrm{C}$ for $30 \mathrm{~s}$, $50^{\circ} \mathrm{C}$ for $30 \mathrm{~s}$ and $72^{\circ} \mathrm{C}$ for $1.5 \mathrm{~min}$, and a final incubation at $72^{\circ} \mathrm{C}$ for $10 \mathrm{~min}$. PCR reaction mixtures were as per the $c y t b$ amplification.

DNA sequencing reactions were performed in both directions with the BigDye Terminator v3.1 Cycle Sequencing Kit (Applied Biosystems). Reactions were modified from the manufacturer's protocols as follows: $0.5 \mu \mathrm{l}$ PCR product was used as template in $10 \mu \mathrm{l}$ reactions containing $0.25 \times$ Ready Reaction Premix, 0.75× BigDye Sequencing Buffer and 1.65 pmol primer. Sequencing reactions were purified with the BigDye XTerminator Purification Kit and analysed on the 3730 DNA Analyzer (Applied Biosystems). 
DNA sequences were evaluated and aligned in Sequencher V4.6 (GeneCodes) and MEGA4. The National Center for Biotechnology Information (NCBI) Basic Local Alignment Search Tool (BLAST) was used to search GenBank for highly similar $16 \mathrm{~S}$ and cytb sequences. Sequence analysis was carried out using MEGA4. Percentage sequence divergences or distances (D) were estimated with the Kimura 2 parameter (K2P) distance model (Kimura 1980). Haplotypes were depicted in neighbour-joining (NJ) trees constructed with the 'pairwise deletion of missing nucleotide data' option. Bootstrap support for each branch point was obtained using 500 replicates. The $16 \mathrm{~S}$ sequences from 3 potential prey species (Squalus acanthias, Hexanchus griseus and broadnose sevengill shark Notorhynchus cepedianus) and Somniosus rostratus obtained from GenBank were included in the NJ tree. Mean within- and between-species distances were determined in MEGA4. Standard error estimates were calculated by bootstrapping 500 times.

Analysis of tooth wear. Teeth of stranded killer whales and museum specimens were assessed for extent of apical tooth wear, either by direct visual inspection of museum specimens or from photographs of stranded or living animals. In most cases, population or lineage affiliation of individuals was determined from natural markings (Ford et al. 2000), but in 2 cases this was determined from DNA analysis. In these cases, a bone sample was obtained from the skull by drilling a $5 \mathrm{~mm}$ diameter hole several $\mathrm{mm}$ deep in the occipital condyle, discarding the shavings and flaming the drill bit to minimise the risk of contamination, and then drilling $\sim 1.5 \mathrm{~cm}$ deeper while retaining the shavings on sterilised foil. The shavings were then digested in Proteinase $\mathrm{K}$ for $24 \mathrm{~h}$ at $54^{\circ} \mathrm{C}$ under gentle rotation. DNA was purified from this solution with phenol and chloroform and precipitated with ethanol, then dried and eluted in $100 \mu \mathrm{l}$ TE buffer following Sambrook et al. (1989). A 262 bp region of the mtDNA CR was amplified using the custom-designed primers LBDL1 (5' TAA ATA ACA CCT GTT GGT TGT G 3') and LBDL3 (5' CAT CTG GTT CTT ACT TCA GGA C 3'). PCR reaction solutions of $25 \mu$ l were prepared using 1 unit of Taq polymerase (New England Biolabs), $1 \times$ PCR reaction buffer (10 mM Tris- $\mathrm{HCl}, \mathrm{pH} 8.3,50 \mathrm{mM} \mathrm{KCl}$, $0.01 \%$ gelatin, $3 \mu \mathrm{g}$ BSA), $3 \mathrm{mM}$ dNTPs, $1.5 \mathrm{mM} \mathrm{MgCl}_{2}$ and 20 pmol of each primer. The PCR thermal profile was $3 \mathrm{~min}$ at $94^{\circ} \mathrm{C}, 31$ cycles of $94^{\circ} \mathrm{C}$ for $50 \mathrm{~s}, 61^{\circ} \mathrm{C}$ for $1 \mathrm{~min}$, and $72^{\circ} \mathrm{C}$ for $3 \mathrm{~min}$, followed by 1 cycle of $72^{\circ} \mathrm{C}$ for $25 \mathrm{~min}$. DNA sequencing was performed in both directions as described by Matkin et al. (2007).

Forward and reverse sequences were manually checked and aligned with sequences for biopsysampled northeastern Pacific killer whales determined by Barrett-Lennard (2000), who described variable sites in the amplified region defining a single haplotype unique to all 7 known offshore killer whales in his dataset. Furthermore, of these 5 sites, 1 distinguished offshores from 119 residents and transients from the northeastern Pacific and from 4 killer whales of unknown population identity from the Atlantic. Here, identification of offshores was considered positive if the diagnostic site as determined in both the forward and reverse sequences matched the site in BarrettLennard's (2000) offshores, and if at least 2 of the other informative sites were clearly resolved and also consistent with Barrett-Lennard's (2000) offshore haplotype.

The degree of apical wear on the crowns of teeth was rated on a scale of 0 (negligible) to 4 (extreme) as described in Table 1. Apical wear was categorised based on the degree of flattening of the tooth crown expressed as a percentage of the tooth diameter at the gum line. In museum specimens, this could be measured directly, but in photos of stranded or living individuals, the rating of tooth wear was estimated.

\section{RESULTS}

\section{Field observations of predation}

During 2 encounters with offshore killer whales, multiple predation events were documented by the collection of tissue fragments from consumed prey. Details of these encounters are as follows:

30 May 2008

A group of 5 offshore killer whales was observed over a period of $8.6 \mathrm{~h}$ at Learmonth Bank, western Dixon Entrance, British Columbia (54 $19^{\prime} \mathrm{N}, 132^{\circ} 56^{\prime} \mathrm{W}$ ) on 30 May 2008. When first encountered at 10:23 h, the whales appeared to be actively foraging. They swam rapidly with frequent changes in direction, and acoustic monitoring revealed considerable vocal activity. Series of short, apparently shallow dives were followed by

Table 1. Orcinus orca. Categories of apical tooth wear

\begin{tabular}{|c|c|c|}
\hline Category & Wear & Crown worn to \\
\hline 0 & Negligible & $\begin{array}{l}<10 \% \text { of diameter of tooth at } \\
\text { gum line }\end{array}$ \\
\hline 1 & Minor & $10-25 \%$ of tooth diameter \\
\hline 2 & Moderate & $25-50 \%$ of tooth diameter \\
\hline 3 & Major & $50-75 \%$ of tooth diameter \\
\hline 4 & Extreme & $\begin{array}{l}75-100 \% \text { of tooth diameter, } \\
\text { exposed pulp cavities in some } \\
\text { or most teeth }\end{array}$ \\
\hline
\end{tabular}


longer dives of 6 to $10 \mathrm{~min}$ duration. Judging from the pronounced arching of the whales' backs as they began a prolonged dive, they were likely diving steeply to considerable depths. Most and occasionally all of the 5 whales were underwater simultaneously on prolonged dives. At 10:45 h, shortly after the whales surfaced from a prolonged dive, a $\sim 250 \mathrm{~g}$ piece of tissue was observed floating at the water surface in a slick of oil near the whales and was collected for DNA analysis. This tissue was soft in consistency and seeped oil, and appeared to be shark liver. At 10:58 h, about $200 \mathrm{~m}$ from the first predation event, several large pieces of similar tissue were observed floating in the vicinity of the whales following a prolonged dive. The movement patterns of the whales suggested strongly that they were sharing food beneath the surface (see Ford \& Ellis 2006 for cues used to infer sharing). Individuals were seen to grasp floating pieces of tissue and carry them beneath the surface, presumably for consumption. A piece of tissue approximately $35 \times 15 \times$ $10 \mathrm{~cm}$ and weighing $\sim 3 \mathrm{~kg}$ was retrieved and a sample collected.

Over the next $7 \mathrm{~h}$, an additional 11 predation events were observed, and each time a sample was collected from pieces of presumed shark liver tissue that were observed floating in the vicinity. Predation events were from 4 to 185 min apart, with a median of 20.5 min (Table 2). Fig. 1 illustrates the spatial distribution of predation events together with the track of the research vessel as it followed the whales. During the $8.6 \mathrm{~h}$ encounter, the whales' foraging was closely focused along an $8 \mathrm{~km}$ section of the steep edge of Learmonth Bank, which drops from $<200 \mathrm{~m}$ to $>500 \mathrm{~m}$ deep in a distance of 1 to $2 \mathrm{~km}$. Predation events were from 0.1 to $1.1 \mathrm{~km}$ apart, with a median distance of $377 \mathrm{~m}$ (Table 1), and took place in waters of 200 to $350 \mathrm{~m}$ depth, although it is not known whether the whales were diving to the bottom. By the end of the foraging session, oil slicks of several $100 \mathrm{~m}^{2}$ in extent were clearly visible on the water surface.

\section{June 2009}

A large group of 100 offshore killer whales was encountered entering Montague Strait, Prince William Sound, Alaska $\left(59^{\circ} 49^{\prime} \mathrm{N}, 148^{\circ} 3^{\prime} \mathrm{W}\right)$ at 09:05 h. The whales were highly dispersed in small subgroups of 1 to 4 individuals over many square $\mathrm{km}$, and frequently made long dives of up to 10 min duration, suggesting that they may have been foraging at depth. At 15:10 h, observers were alerted to the presence of prey remains at the surface by gulls picking up bits of tissue, and a piece of floating shark liver was collected. Over the next $3 \mathrm{~h}$, an additional 6 predation events were observed and a sample of shark liver was collected from each (Table 2). Predation events took place from 0.2 to $4.9 \mathrm{~km}$ apart (median $=1.8 \mathrm{~km}$ ) as the whales foraged northward up Montague Strait. Liver remains often floated to the surface several min after foraging whales had continued on, suggesting that predation and consumption was taking place at depth. Predation

Table 2. Orcinus orca. Details of predation events by offshore killer whales at Learmonth Bank, British Columbia (30 May 2008), and Montague Strait, Prince William Sound, Alaska (13 June 2009). CR: control region

\begin{tabular}{|c|c|c|c|c|c|c|c|}
\hline \multirow[t]{2}{*}{ Date } & \multirow{2}{*}{$\begin{array}{c}\text { Predation } \\
\text { event }\end{array}$} & \multirow{2}{*}{$\begin{array}{l}\text { Local time } \\
\text { (h) }\end{array}$} & \multirow[t]{2}{*}{ Latitude } & \multirow[t]{2}{*}{ Longitude } & \multicolumn{2}{|c|}{ Previous predation event } & \multirow{2}{*}{$\begin{array}{l}\text { Shark CR } \\
\text { haplotype }\end{array}$} \\
\hline & & & & & Distance $(\mathrm{km})$ & Time (min) & \\
\hline \multirow[t]{13}{*}{30 May 2008} & 1 & $10: 45$ & 54.378 & -132.945 & & & H01 \\
\hline & 2 & $10: 58$ & 54.378 & -132.948 & 0.216 & 13 & H02 \\
\hline & 3 & 11:06 & 54.377 & -132.947 & 0.172 & 8 & H02 \\
\hline & 4 & $11: 52$ & 54.374 & -132.957 & 0.728 & 46 & H03 \\
\hline & 5 & $12: 20$ & 54.373 & -132.959 & 0.149 & 28 & - \\
\hline & 6 & $12: 41$ & 54.363 & -132.962 & 1.125 & 21 & H04 \\
\hline & 7 & $13: 21$ & 54.358 & -132.975 & 1.027 & 40 & H05 \\
\hline & 8 & $13: 41$ & 54.355 & -132.990 & 1.040 & 20 & H05 \\
\hline & 9 & $13: 45$ & 54.357 & -132.993 & 0.285 & 4 & H06 \\
\hline & 10 & $13: 52$ & 54.355 & -132.995 & 0.177 & 7 & H07 \\
\hline & 11 & $13: 59$ & 54.356 & -132.996 & 0.102 & 7 & H08 \\
\hline & 12 & $14: 52$ & 54.355 & -133.008 & 0.842 & 60 & H09 \\
\hline & 13 & $17: 57$ & 54.353 & -133.015 & 0.470 & 185 & H08 \\
\hline \multirow[t]{7}{*}{13 June 2009} & 1 & $15: 10$ & 60.070 & -147.755 & & & H08 \\
\hline & 2 & $16: 00$ & 60.105 & -147.700 & 4.944 & 50 & H06 \\
\hline & 3 & $16: 20$ & 60.105 & -147.689 & 0.610 & 20 & $\mathrm{H} 10$ \\
\hline & 4 & $17: 00$ & 60.128 & -147.705 & 2.706 & 40 & H09 \\
\hline & 5 & $17: 15$ & 60.142 & -147.720 & 1.764 & 15 & H07 \\
\hline & 6 & $17: 38$ & 60.152 & -147.727 & 1.177 & 23 & H11 \\
\hline & 7 & $18: 10$ & 60.170 & -147.727 & 2.001 & 32 & H05 \\
\hline
\end{tabular}




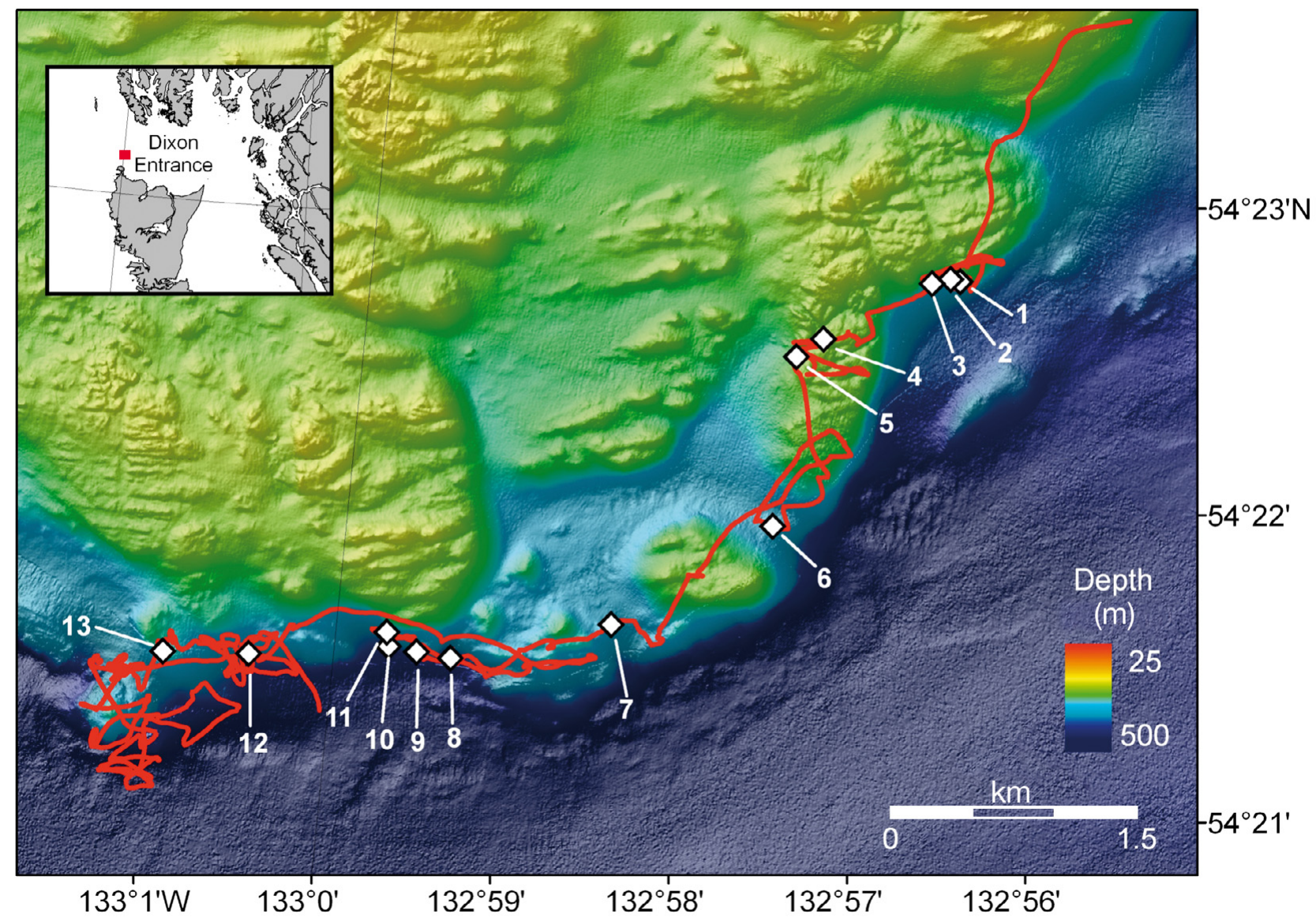

Fig. 1. Orcinus orca. Bathymetric map showing track of research vessel (red line) as it followed offshore killer whales and locations of predation events $(\diamond)$ of Pacific sleeper sharks at Learmonth Bank, British Columbia, on 30 May 2008. Predation events are numbered sequentially with details provided in Table 2. Water depth: see colour shade in the legend. Inset: Learmonth Bank in Dixon Entrance (匹)

events took place in locations with water depths of 180 to $300 \mathrm{~m}$. Gulls were seen picking up prey remains in the vicinity of distant subgroups of whales, suggesting that more predation events took place than the 7 from which samples were collected.

\section{Genetic identification of prey samples}

Three 16S haplotypes (HM536174, HM536175 and HM536176) were observed among the 20 prey tissues analysed (Fig. 2). Eighteen samples possessed a haplotype identical to the GenBank Somniosus pacificus AY835659 sequence. Each of the 2 new haplotypes differed from AY835659 by a single transitional base substitution. The cytb sequences, HQ260437 and HQ260438, obtained for these two 16S haplotypes were identical to the H4 Somniosus spp. haplotype (EF090952) reported by Murray et al. (2008).

The prey tissue $16 \mathrm{~S}$ sequences formed a tight Somniosus pacificus cluster $(\mathrm{D}=0.1 \%, \mathrm{SE}=0.1 \%)$. The
S. pacificus sequences also grouped closely with the AY462193 sequence from $S$. rostratus, with a mean inter-specific D value of $1.4 \%$ (SE $=0.7 \%$ ). However, discrimination of these congeners was supported by a high bootstrap value ( $99 \%$ ). The $16 \mathrm{~S}$ sequences for the other 3 eastern Pacific shark species each formed distinct species clusters and all were highly differentiated from the $S$. pacificus sequences (Fig. 2). The overall mean interspecific D value for the 4 eastern Pacific shark species was $14.2 \%$ and ranged from 8.4 ( $\mathrm{SE}=$ $2.0 \%)$ to $19.6 \%(\mathrm{SE}=3.4 \%)$.

In total, 11 CR haplotypes (HQ237466-HQ237476) were observed among 19 prey tissues (no CR sequence data were obtained for LB-5), 9 among 12 prey tissue samples from Learmonth Bank and 7 among the 7 samples from Montague Strait. Samples collected from 2 predation events that were only $13 \mathrm{~min}$ and about 200 m apart (events $2 \& 3$ ) shared the same haplotype, and it is possible that only 1 fish was involved. Killer whales will occasionally transport prey for 100 to $200 \mathrm{~m}$ while feeding, especially when sharing food with other 
Fig. 2. Neighbour-joining trees of mitochondrial sequences from shark predation events at Learmonth Bank (LR1-13) and Montague Strait (MS1-7), and 5 shark species standards. The trees were constructed with pairwise percentage differentiation (D) values for (a) $224 \mathrm{bp}$ of $16 \mathrm{~S}$ and (b) 901 bp of control region $(\mathrm{CR})$ sequences
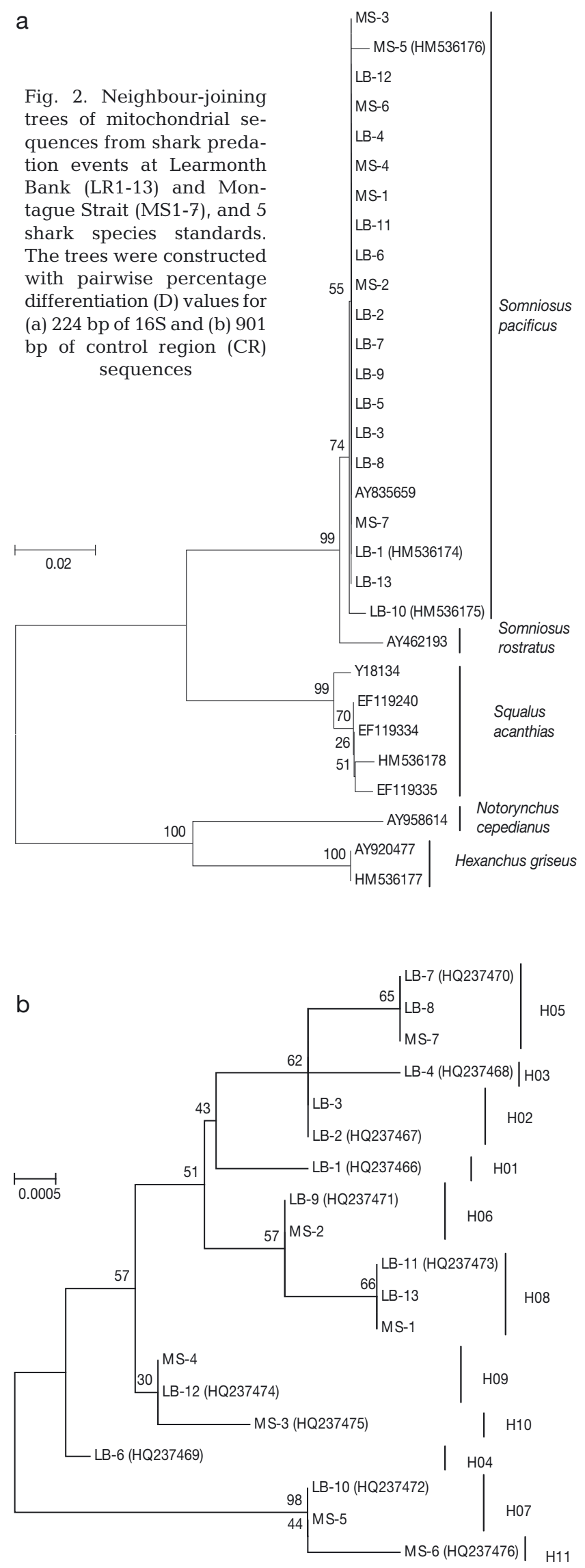

whales (Ford \& Ellis 2006). Predation events 7 \& 8 on 30 May 2008 also involved the same haplotype, but given the separation of these events in space and time (>1 $\mathrm{km}$ and $20 \mathrm{~min}$ apart), we consider it unlikely that a single fish was involved. Predation events 11 \& 13 both involved a single haplotype, but these were $>3 \mathrm{~h}$ apart and thus almost certainly involved 2 different fish. From this we conclude that a minimum of 9 but likely at least 11 individual sharks were taken on 30 May 2008. Each of the 7 predation events sampled on 13 June 2009 represented distinct haplotypes, and thus we can conclude that these samples came from 7 individual sharks.

\section{Comparative tooth wear in killer whale lineages}

Table 3 describes the results of an analysis of apical tooth wear in 27 killer whales, including 9 offshore, 8 transient and 10 resident individuals. Examples of typical tooth wear in the 3 lineages are shown in Fig. 3, and photos of teeth of each individual in Table 1 are given in the supplement at www.int-res.com/articles/suppl/b011 p213_supp.pdf. Although considerable wear was often evident on the anterior and posterior faces of teeth in older resident and transient individuals, wear of the tooth crown was negligible to moderate (ratings 0 to 2 ) in all cases. In most offshore killer whale specimens, tooth wear was categorised as extreme (rating 4). Teeth were usually worn flat to the gum line, with exposed pulp cavities in the anterior 6 to 8 rows of mandibular teeth. Tooth wear in resident and transient killer whales examined was not sufficient to expose pulp cavities. The only offshore individual with minor tooth wear was a young whale (3.23 m long, no. 20 in Carl 1945).

\section{DISCUSSION}

Predation events on Pacific sleeper sharks described here are the first cases where the identity of prey species of offshore killer whales in the northeastern Pacific could be confirmed from analysis of prey fragments recovered from kill sites, and the first records of predation by killer whales on the genus Somniosus. All prey tissues in this study were identified as $S$. pacificus on the basis of their complete sequence match to published $16 \mathrm{~S}$ or $c y t b$ sequences for this species and the limited $16 \mathrm{~S}$ sequence variability observed among them. The latter is generally consistent with the prey tissues having originated from a single species, $S$. pacificus (Greig et al. 2005, Ward et al. 2008). Other eastern Pacific species, including spiny dogfish, bluntnose sixgill shark and broadnose sevengill shark were excluded as potential candidates because their 16S 
Table 3. Orcinus orca. Extent of apical tooth wear in 27 killer whales determined from examination of beach-cast carcasses, museum specimens or living animals. Under 'Lineage', O: offshore $(n=9)$, R: resident $(n=10), T$ : transient $(n=8)$ killer whales. ID: individual identifications from Carl (1945), Ford \& Ellis (1999), Ford et al. (2000) or from catalogues maintained at the Pacific Biological Station (PBS), Nanaimo, British Columbia (BC). Locations are in BC unless otherwise noted. 'Source' lists photos in published reports or on file at PBS, and accession numbers of specimens at the Royal British Columbia Museum (RBCM). Age is given in years where known, or as SA (subadult) and A (adult) if estimated from length. Under 'Evidence', S indicates that specimens of extracted teeth were examined and P indicates that photos of stranded or live animals were examined. Apical tooth wear categories range from 0 (negligible) to 4 (extreme; see Table 1 and 'Materials and methods' for details)

\begin{tabular}{|c|c|c|c|c|c|c|c|c|c|}
\hline Lineage & ID & Sex & Age & $\begin{array}{l}\text { Length } \\
\text { (m) }\end{array}$ & $\begin{array}{c}\text { Date } \\
\text { (YYYY-MM-DD) }\end{array}$ & Location & Source & Evidence & $\begin{array}{l}\text { Apical } \\
\text { wear }\end{array}$ \\
\hline $\mathrm{O}^{\mathrm{a}}$ & 11 & $\mathrm{~F}$ & SA & 4.67 & 1945-07-01 & Estevan Point & Carl (1945), RBCM5214 & $\mathrm{S}$ & $2,3,4$ \\
\hline $\mathrm{O}^{\mathrm{a}}$ & 13 & $\mathrm{~F}$ & A & 5.64 & 1945-07-01 & Estevan Point & Carl (1945) & $\mathrm{P}$ & 4 \\
\hline $\mathrm{O}^{\mathrm{a}}$ & 17 & $\mathrm{~F}$ & $\mathrm{~A}$ & 5.53 & $1945-07-01$ & Estevan Point & Carl (1945) & $\mathrm{P}$ & 4 \\
\hline $\mathrm{O}^{\mathrm{a}}$ & 20 & M & SA & 3.23 & $1945-07-01$ & Estevan Point & Carl (1945) & $\mathrm{P}$ & 1,2 \\
\hline $\mathrm{O}^{\mathrm{a}}$ & & M & A & 6.45 & $1955-05-19$ & Coal Harbour & PBS & $\mathrm{P}$ & 4 \\
\hline $\mathrm{O}^{\mathrm{b}}$ & & $\mathrm{F}$ & $\mathrm{A}$ & 5.18 & $1961-11-18$ & Newport, CA & Caldwell \& Brown (1964) & $\mathrm{P}$ & 4 \\
\hline $\mathrm{T}$ & $\mathrm{T} 2$ & $\mathrm{~F}$ & 20 & & $1970-06$ & Pedder Bay & Pike \& MacAskie (1969) PBS & $\mathrm{P}$ & 0 \\
\hline $\mathrm{R}$ & B4 & M & 11 & 4.62 & 1973-08-07 & Alert Bay & RBCM8386 & $\mathrm{S}$ & 0 \\
\hline $\mathrm{T}^{\mathrm{c}}$ & & $\mathrm{M}$ & $20+$ & 6.81 & 1976-04-09 & Tofino & RBCM12844 & $\mathrm{S}$ & 1 \\
\hline $\mathrm{T}$ & O1 & M & $\mathrm{A}$ & 6.99 & 1979-01-18 & Boundary Bay & RBCM10001 & $\mathrm{P}, \mathrm{S}$ & 1 \\
\hline $\mathrm{T}^{\mathrm{c}}$ & & M & SA & 4.5 & $1981-06-23$ & Bamfield & RBCM10402 & $\mathrm{P}, \mathrm{S}$ & 0 \\
\hline $\mathrm{R}$ & L66 & $\mathrm{F}$ & $60+$ & 6.32 & $1986-08-17$ & Port Renfrew & RBCM16006 & $\mathrm{S}$ & 1 \\
\hline $\mathrm{R}$ & L14 & $\mathrm{M}$ & 17 & 6.11 & 1989-04-11 & Barkley Sound & RBCM16814 & $\mathrm{S}$ & 0,1 \\
\hline $\mathrm{T}^{\mathrm{c}}$ & & $\mathrm{F}$ & A & 6.18 & $1990-07-28$ & Dundas I & PBS & $\mathrm{P}$ & 1,2 \\
\hline $\mathrm{R}$ & A9 & $\mathrm{F}$ & 56 & 6.07 & 1990-12-01 & Telegraph Cove & PBS & $\mathrm{P}, \mathrm{S}$ & 0,2 \\
\hline $\mathrm{R}^{\mathrm{a}}$ & & $\mathrm{M}$ & $20+$ & 6.78 & $1993-06-02$ & Manley Island & PBS & $\mathrm{P}$ & 0 \\
\hline $\mathrm{O}$ & & $\mathrm{F}$ & A & & $1994-10-13$ & Barnes Lake, AK & PBS & $\mathrm{P}$ & 4 \\
\hline $\mathrm{O}$ & & M & SA & & $1994-10-13$ & Barnes Lake, AK & PBS & $\mathrm{P}$ & 4 \\
\hline $\mathrm{R}$ & $\mathrm{J} 4$ & $\mathrm{~F}$ & 38 & 6.18 & $1995-12-12$ & Texada I & PBS & $\mathrm{P}, \mathrm{S}$ & 0,1 \\
\hline $\mathrm{R}^{\mathrm{a}}$ & $\sqrt{4}$ & $\mathrm{~F}$ & $\mathrm{~A}$ & 6.3 & $1996-05-21$ & Cape Scott & PBS & $\begin{array}{l}1, \mathrm{~N} \\
\mathrm{P}\end{array}$ & $\begin{array}{c}0 \\
0 \\
1\end{array}$ \\
\hline $\mathrm{O}$ & O120 & $\mathrm{F}$ & $\mathrm{A}$ & 5.5 & $1997-08-29$ & Hot Springs Cove & PBS & $\mathrm{P}, \mathrm{S}$ & 4 \\
\hline $\mathrm{R}$ & L51 & $\mathrm{F}$ & 26 & 6.03 & $1999-09-26$ & Race Rocks & PBS & $\mathrm{P}$ & 0 \\
\hline $\mathrm{R}$ & $\mathrm{J} 18$ & M & 23 & 6.5 & 2000-03-18 & Boundary Bay & PBS & $\mathrm{P}, \mathrm{S}$ & 0 \\
\hline $\mathrm{R}$ & $\mathrm{C} 21$ & $\mathrm{~F}$ & 12 & 5.49 & 2006-07-18 & Prince Rupert & PBS & $\mathrm{P}$ & 0 \\
\hline $\mathrm{T}^{\mathrm{c}}$ & & $\mathrm{F}$ & $\mathrm{A}$ & & $2007-05-18$ & Nootka I & PBS & $\mathrm{P}$ & 0 \\
\hline $\mathrm{T}$ & $\mathrm{T} 44$ & M & 31 & & 2009-03-29 & Goletas Channel & PBS & $\mathrm{P}, \mathrm{S}$ & 0 \\
\hline $\mathrm{T}^{\mathrm{c}}$ & & $\mathrm{F}$ & $\mathrm{A}$ & 5.85 & 2009-08-02 & Price I & PBS & $\mathrm{P}$ & 1 \\
\hline \multicolumn{10}{|c|}{$\begin{array}{l}{ }^{\mathrm{a}} \text { Determined by analysis of mtDNA from bone (this study) or tissue samples (Ford et al. 1998) } \\
{ }^{b} \text { Determined by Morin et al. (2006) } \\
\text { c Inferred from stomach contents }\end{array}$} \\
\hline
\end{tabular}

sequences were significantly different from the $S$. pacificus sequences observed. Congeneric species $S$. rostratus and $S$. antarcticus having similar or identical $16 \mathrm{~S}$ or $c y t b$ sequences were excluded as species candidates, since their published distributions were outside of the eastern Pacific collection area for the offshore killer whale prey tissues (Compagno 1984, Masuda et al. 1984, Murray et al. 2008).

A minimum of 16 but more likely 18 individual Somniosus pacificus were involved in predation events sampled at Learmonth Bank, British Columbia, and Montague Strait, Prince William Sound, Alaska. During both encounters, whales appeared to be diving steeply and repeatedly to forage at depth, and the frequency of kills of this 1 species suggests that the whales were specifically targeting sleeper sharks.

The Pacific sleeper shark has several attributes that make it a desirable and potentially important food resource for offshore killer whales. It is a common shark of the North Pacific continental shelf and slope, ranging in the northeastern Pacific from the Bering Sea to Baja California, Mexico (Sigler et al. 2006), which encompasses the known range of offshore killer whales (Black et al. 1997, Ford et al. 2000, Dahlheim et al. 2008). It is a large shark that may reach total lengths of $>7 \mathrm{~m}$, although individuals with a pre-caudal length of $>3 \mathrm{~m}$ are rare (Hulbert et al. 2006). The median precaudal length of 429 sleeper sharks measured from Prince William Sound was $1.7 \mathrm{~m}$ (range 0.6 to $2.8 \mathrm{~m}$ ) (Hulbert et al. 2006), and sleeper sharks with similar lengths from waters off southern Alaska had masses of 15 to $215 \mathrm{~kg}$ (Sigler et al. 2006). Pacific sleeper sharks are active predators that undergo vertical movements in the water column. Sleeper sharks tagged in Alaska tended to move into shallower water during the night and deeper water during day and had an overall 

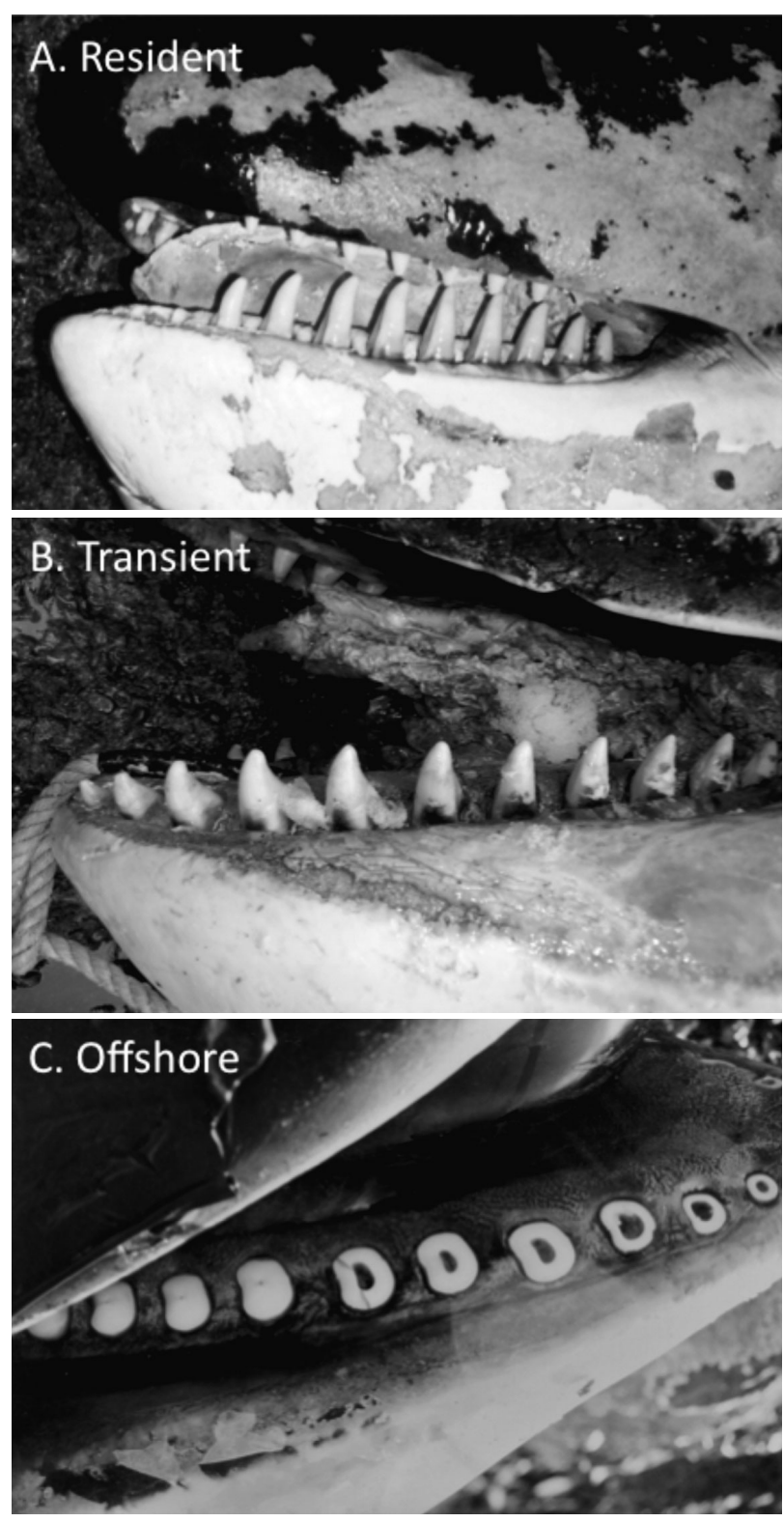

Fig. 3. Orcinus orca. Representative photographs of killer whale teeth: (A) resident female A9, (B) transient male T44 and (C) offshore female O120 (all adults). Photo (C) by R. Palm

median daily depth range of $184 \mathrm{~m}$ (range of daily medians $=116$ to $254 \mathrm{~m}$, Hulbert et al. 2006). These depths are similar to those at the locations of Somniosus pacificus predation observed here, and are within the maximum dive depths observed in piscivorous resident killer whales (Baird et al. 2005; J. Ford \& G. Ellis unpubl. data)

Like most deep water sharks, Somniosus have a very large liver that is rich in lipids (up to $80 \%$ by weight), which appears to serve in buoyancy control at depth (Phleger 1998). A 3.93 m Pacific sleeper shark esti- mated to weigh $\sim 900 \mathrm{~kg}$ had a liver of $\sim 180 \mathrm{~kg}$ (Bright 1959 ), or $\sim 20 \%$ of its total mass. Thus, a median sized $1.7 \mathrm{~m}$ sleeper shark (Hulbert et al. 2006) having a mass of $75 \mathrm{~kg}$ (L. Hulbert pers. comm.) would have a liver of $\sim 15 \mathrm{~kg}$. Given the high lipid content of shark liver, this represents a substantial, high energy food source for a killer whale.

Piscivorous killer whales appear to select prey at least partly on the basis of size and lipid content. Resident killer whales forage selectively for Chinook salmon, which is the largest and most lipid rich of the Pacific salmon species (Ford \& Ellis 2006), and killer whales that take fish from longline fishing gear tend to select the largest individuals of lipid-rich species and shun smaller or lipid-poor species (Matkin \& Saulitis 1994, Yano \& Dahlheim 1995). Although offshore killer whales were observed to retrieve and presumably feed on pieces of sleeper shark liver, it is not known if other parts of the shark flesh were eaten. The whales may have fed selectively on the liver because it seems unlikely that 5 killer whales would consume the flesh of 11 sleeper sharks in a single day (30 May 2008), given the median size of the sharks observed in Alaska (1.7 m, $75 \mathrm{~kg})$. Pyle et al. (1999) observed 2 killer whales preying on a 3 to $4 \mathrm{~m}$ long white shark Carcharodon carcharias and noted that only the liver was consumed. Mammal-hunting killer whales often strip porpoises of their blubber and discard the remainder of the carcass (J. Ford, G. Ellis, L. Barrett-Lennard unpubl. data). Furthermore, the musculature of the congeneric Greenland sleeper shark Somniosus microcephalus contains high levels of trimethylamine and is poisonous to humans and dogs (Bagnis et al. 1970, Anthoni et al. 1991). S. pacificus muscle may be similarly toxic, possibly to whales as well.

Although the foraging activities of offshore killer whales on the 2 occasions described here appeared to be focused on Pacific sleeper sharks, the importance of sharks in the diet of this lineage is unclear. However, the stomach contents collected from known offshores (blue or whitetip shark, opah, and halibut; Rice 1968, Morin et al. 2006, this study) suggest that sharks and large teleost fish may be important. This is consistent with the findings of Krahn et al. (2007), who concluded from analyses of fatty acids, stable isotopes and persistent organic pollutant (POP) levels that the diet of offshore killer whales likely consists of long-lived, high trophic level marine fishes.

The tooth wear of offshore killer whales provides further evidence that their diet is distinct from that of resident or transient killer whales. The teeth of offshore killer whales we examined had severe apical wear; the mandibular teeth were often worn to the gum line and exhibited exposed pulp cavities. In contrast, apical tooth wear in adult resident and transient killer whales 
was generally negligible, even in old individuals, suggesting that diets consisting primarily of pinnipeds and cetaceans (transients), or of teleost fish such as salmon (residents; Ford et al. 1998), do not result in apical tooth wear. Thus, it seems likely that the diet of offshore killer whales includes prey species that are unusually abrasive to their teeth.

We propose that the hardened dermal denticles (placoid scales) embedded in the skin of sharks contribute to the pattern of tooth wear seen in offshore killer whales. Shark skin has long been valued for its abrasive qualities (Raschi \& Tabit 1992) and from ancient times through to the Middle Ages, it was commonly used for smoothing and polishing artworks made from ivory and bone (Cristoferi \& Fiori 1992), which attests to the potential effect that shark skin may have on killer whale teeth. The dermal denticles of elasmobranchs vary widely in morphology (Raschi \& Tabit 1992), with deep-water sharks, including Somniosus, having particularly rough skin with placoid scales that have erect, narrow crowns and hooked cusps (Raschi \& Tabit 1992, Yano et al. 2004).

Since the pulp cavity of killer whale teeth becomes increasingly occluded with maturity (Perrin \& Myrick 1980), the presence of open pulp cavities in worn teeth in most offshore killer whale specimens suggests that significant wear begins at an early age. In cases where most or all teeth are worn flat to the gum line, the large open pulp cavities of anterior teeth and the much smaller cavities of posterior teeth (see Fig. 3) suggest that apical wear begins in anterior teeth and continues progressively over time towards the posterior teeth. Caldwell \& Brown (1964) suggested that this is due to prey being grasped mostly by the anterior teeth, which are then subjected to abrasion as the whale twists and shakes its head to tear and break apart the carcass. How extreme tooth wear may affect a whale's ability to catch and consume prey is unknown. However, if tooth wear is debilitating, food sharing and provisioning, as described in other killer whale populations (Hoelzel 1991, Ford \& Ellis 2006), may be of particular importance within groups of offshore killer whales.

If the extreme tooth wear seen in offshore killer whales is due to abrasion from shark skin, this implies that elasmobranchs may represent a major component of their diet. Various species of sharks and rays have been documented as prey of killer whales in different regions (Fertl et al. 1996, Visser 2005). Predation on sharks and rays has been observed with sufficient frequency in a population of killer whales in New Zealand that it has been proposed that this population may specialise on elasmobranch prey (Visser 2005). Offshore killer whales of the northeastern Pacific may also specialise, although the presence of teleost fish in stomach contents indicates that they are not exclu- sively shark feeders. This does not preclude specialisation on sharks, however, as resident killer whales that prey primarily on salmonids occasionally take nonsalmonid prey (Ford et al. 1998, Ford \& Ellis 2006). The abundance of Pacific sleeper sharks, blue sharks, salmon sharks Lamna ditropis and spiny dogfish (Wright \& Hulbert 2000, Nakano \& Seki 2003) in the northeastern Pacific may represent a valuable prey resource for offshore killer whales. Ecological specialisation with accompanying social and reproductive isolation of offshores from the salmonid-eating resident and mammal-eating transient killer whales may have been important in the genetic divergence of these lineages (Morin et al. 2010). However, further documentation of the predatory habits of northeastern Pacific offshore killer whales is clearly needed to determine whether these whales are as ecologically specialised as other killer whale populations, and to establish the importance of elasmobranchs in such specialisation.

Acknowledgements. We thank M. Boogaards for assistance with sample processing and R. Abernethy for preparing the map. L. Hulbert kindly provided information on Pacific sleeper shark mass and length, and R. Palm assisted with the necropsy and provided photographs of offshore whale O120. We thank D. Bain for photographs of stranded killer whales from Barnes Lake, AK. A. Miscampbell assisted with the sequencing of killer whale bone samples in the Genetic Data Centre at the University of British Columbia. J. King provided the Squalus acanthias and Hexanchus griseus tissue samples. This work was funded by the Species at Risk Program of Fisheries and Oceans Canada and supported logistically by Langara Fishing Lodge. Earlier drafts of this manuscript were improved by comments from J. Watson and 3 anonymous reviewers.

\section{LITERATURE CITED}

Anthoni U, Christophersen C, Gram L, Nielsen NH, Nielsen P (1991) Poisonings from the flesh of the Greenland shark Somniosus microcephalus may be due to trimethylamine. Toxicon 29:1205-1212

Bain DE (1995) The use of sound to guide killer whales (Orcinus orca) entrapped in Barnes Lake, Alaska, to open water. 11th Bienn Conf Biol Mar Mamm, 14-18 December 1995, Orlando, FL, p 6

Bagnis R, Berglund F, Elias PS, van Esch PJ, Halstead BW, Kojima K (1970) Problems of toxicants in marine food products. 1. Marine biotoxins. Bull WHO 42:69-88

Baird RW, Whitehead H (2000) Social organisation of mammal-eating killer whales: group stability and dispersal patterns. Can J Zool 78:2096-2105

Baird RW, Abrams PA, Dill LM (1992) Possible indirect interactions between transient and resident killer whales: implications for the evolution of foraging specializations in the genus Orcinus. Oecologia 89:125-132

Baird RW, Hanson MB, Dill LM (2005) Factors influencing the diving behaviour of fish-eating killer whales: sex differences and diel and interannual variation in diving rates. Can J Zool 83:257-267

Barrett-Lennard LG (2000) Population structure and mating 
systems of northeastern Pacific killer whales. PhD dissertation, University of British Columbia, Vancouver

Barrett-Lennard LG, Ford JKB, Heise KA (1996) The mixed blessing of echolocation: differences in sonar use by fisheating and mammal-eating killer whales. Anim Behav 51: 553-565

Bigg MA (1982) An assessment of killer whale (Orcinus orca) stocks off Vancouver Island, British Columbia. Rep Int Whaling Comm 32:655-666

Bigg MA, MacAskie IB, Ellis G (1976) Abundance and movements of killer whales off eastern and southern Vancouver Island with comments on management. Arctic Biological Station, Canadian Dept. of Fisheries and Environment, Ste Anne-de-Bellevue, QC

Bigg MA, Olesiuk PF, Ellis GM, Ford JKB, Balcomb KC III (1990) Social organization and genealogy of resident killer whales (Orcinus orca) in the coastal waters of British Columbia and Washington State. Rep Int Whaling Comm 12(Spec Issue):383-405

Black NA, Schulman-Janiger A, Ternullo RL, Guerrero-Ruiz M (1997) Killer whales of California and western Mexico: a catalog of photo-identified individuals. Nat Mar Fish Serv Rep NOAA-TM-NMFS-SWFSC-247, La Jolla, CA

Blanco M, Pérez-Martín RI, Sotelo CG (2008) Identification of shark species in seafood products by forensically informative nucleotide sequencing (FINS). J Agric Food Chem 56:9868-9874

Bright DB (1959) The occurrence and food of the sleeper shark, Somniosus pacificus, in a central Alaska bay. Copeia 1959:76-77

Caldwell DK, Brown DH (1964) Tooth wear as a correlate of described feeding behavior by the killer whale, with notes on a captive specimen. Bull South Calif Acad Sci 63: $128-140$

Carl GC (1945) A school of killer whales stranded at Estevan Point, Vancouver Island. Rep Prov Mus Nat Hist Anthropol 1945:B21-B28

Compagno LJV (1984) FAO species catalogue. Vol. 4. Sharks of the world. An annotated and illustrated catalogue of shark species known to date. 1. Hexanchiformes to Lamniformes. FAO Fish Synop 125:1-249

COSEWIC (Committee on the Status of Endangered Wildlife in Canada) (2008) COSEWIC assessment and update status report on the killer whale Orcinus orca, southern resident population, northern resident population, west coast transient population, offshore population and northwest Atlantic/eastern Arctic population, in Canada. COSEWIC, Ottawa

Cristoferi E, Fiori C (1992) Polishing treatments on ivory materials in the national museum in Ravenna. Stud Conserv 37:259-266

Dahlheim ME, Schulman-Janiger A, Black N, Ternullo R, Ellifrit D, Balcomb KC (2008) Eastern temperate North Pacific offshore killer whales (Orcinus orca): occurrence, movements, and insights into feeding ecology. Mar Mamm Sci 24:719-729

$>$ Deagle BE, Tollit DJ, Jarman SN, Hindell MA, Trites AW, Gales NJ (2005) Molecular scatology as a tool to study diet: analysis of prey DNA in scats from captive Steller sea lions. Mol Ecol 14:1831-1842

> Deecke VB, Ford JKB, Slater P (2005) The vocal behaviour of mammal-eating killer whales: communicating with costly calls. Anim Behav 69:395-405

> Fertl D, Acevedo-Gutierrez A, Darby FL (1996) A report of killer whales (Orcinus orca) feeding on a carcharhinid shark in Costa Rica. Mar Mamm Sci 12:606-611

Foote AD, Newton J, Piertney SB, Willerslev E, Gilbert MTP
(2009) Ecological, morphological and genetic divergence of sympatric North Atlantic killer whale populations. Mol Ecol 18:5207-5217

Ford JKB (2009) Killer whales Orcinus orca. In: Perrin WF, Würsig B, Thewissen JGM (eds) The encyclopedia of marine mammals, 2nd edn. Elsevier, New York, NY

Ford JKB, Ellis GM (1999) Transients: mammal-hunting killer whales of British Columbia, Washington, and southeastern Alaska, UBC Press, Vancouver, BC

Ford JKB, Ellis GM (2006) Selective foraging by fish-eating killer whales Orcinus orca in British Columbia. Mar Ecol Prog Ser 316:185-199

Ford JKB, Fisher HD (1982) Killer whale (Orcinus orca) dialects as an indicator of stocks in British Columbia. Rep Int Whaling Comm 32:671-679

Ford JKB, Ellis FM, Nichol LM (1992) Killer whales of the Queen Charlotte Islands. A preliminary study of the abundance, distribution, and population identity of Orcinus orca in the waters of Haida Gwaii, South Moresby/Haida Gwaii Haanas National Parks Reserve, Canadian Parks Service, Queen Charlotte City

Ford JKB, Ellis GM, Barrett-Lennard LG, Morton AB, Palm RS, Balcomb KC III (1998) Dietary specialization in two sympatric populations of killer whales (Orcinus orca) in coastal British Columbia and adjacent waters. Can J Zool 76:1456-1471

Ford JKB, Ellis GM, Balcomb KC (2000) Killer whales: the natural history and genealogy of Orcinus orca in the waters of British Columbia and Washington. UBC Press, Vancouver, $\mathrm{BC}$, and University of Washington Press, Seattle, WA

Funk DJ, Nosil P, Etges WJ (2006) Ecological divergence exhibits consistently positive associations with reproductive isolation across disparate taxa. Proc Natl Acad Sci USA 103:3209-3213

Greig TW, Moore MK, Woodley CM, Quattro JM (2005) Mitochondrial gene sequences useful for species identification of western North Atlantic Ocean sharks. Fish Bull 103: $516-523$

> Heise K, Barrett-Lennard LG, Saulitis E, Matkin C, Bain D (2003) Examining the evidence for killer whale predation on Steller sea lions in British Columbia and Alaska. Aquat Mamm 29:325-334

> Herman DP, Burrows DG, Wade PR, Durban JW, Matkin CO, LeDuc RG, Barrett-Lennard LG, Krahn MM (2005) Feeding ecology of eastern North Pacific killer whales Orcinus orca from fatty acid, stable isotope, and organochlorine analyses of blubber biopsies. Mar Ecol Prog Ser 302: $275-291$

Hoelzel AR (1991) Killer whale predation on marine mammals at Punta Norte, Argentina: food sharing, provisioning and foraging strategy. Behav Ecol Sociobiol 29:197-204

Hoelzel AR, Dover GA (1991) Genetic differentiation between sympatric killer whale populations. Heredity 66:191-195

> Hoelzel AR, Natoli A, Dahlheim ME, Olavarria C, Baird RW, Black NA (2002) Low worldwide genetic diversity in the killer whale: implications for demographic history. Proc Biol Sci 269:1467-1473

Hulbert LB, Sigler MF, Lunsford CR (2006) Depth and movement behaviour of the Pacific sleeper shark in the northeast Pacific Ocean. J Fish Biol 69:406-425

> Jones IM (2006) A northeast Pacific offshore killer whale (Orcinus orca) feeding on a Pacific halibut (Hippoglossus stenolepis). Mar Mamm Sci 22:198-200

Keeney DB, Heupel M, Hueter RE, Heist EJ (2003) Genetic heterogeneity among blacktip shark, Carcharhinus limbatus, continental nurseries along the U.S. Atlantic and Gulf of Mexico. Mar Biol 143:1039-1046 
Kimura M (1980) A simple method for estimating evolutionary rates of base substitutions through comparative studies of nucleotide sequences. J Mol Evol 16:111-120

Krahn MM, Herman DP, Matkin CO, Durban JW and others (2007) Use of chemical tracers in assessing the diet and foraging regions of eastern North Pacific killer whales. Mar Environ Res 63:91-114

LeDuc RG, Robertson KM, Pitman RL (2008) Mitochondrial sequence divergence among Antarctic killer whale ecotypes is consistent with multiple species. Biol Lett 4: $426-429$

Masuda H, Amaoka K, Araga C, Uyeno T, Yoshino T (1984) The fishes of the Japanese Archipelago, Vol. 1. Tokai University Press, Tokyo

Matkin CO, Saulitis EL (1994) Killer whale (Orcinus orca) biology and management in Alaska. Rep No. T75135023, Marine Mammal Commission, Washington, DC

Matkin CO, Barrett-Lennard LG, Yurk H, Ellifrit D, Trites AW (2007) Ecotypic variation and predatory behavior among killer whales (Orcinus orca) off the eastern Aleutian Islands, Alaska. Fish Bull 105:74-87

Morin PA, Leduc RG, Robertson KM, Hedrick NM and others (2006) Genetic analysis of killer whale (Orcinus orca) historical bone and tooth samples to identify western U.S. ecotypes. Mar Mamm Sci 22:897-909

Morin PA, Archer FI, Foote, AD, Vilstrup J and others (2010) Complete mitochondrial genome phylogeographic analysis of killer whales (Orcinus orca) indicates multiple species. Genome Res 20:908-916

Murray BW, Wang JY, Yang S, Stevens JD, Fisk A, Svavarsson J (2008) Mitochondrial cytochrome $b$ variation in sleeper sharks (Squaliformes: Somniosidae). Mar Biol 153: 1015-1022

Nakano H, Seki MP (2003) Synopsis of biological data on the blue shark, Prionace glauca Linnaeus. Bull Fish Res Agency 6:18-55

Perrin WF, Myrick ACJ (1980) Age determination of toothed whales and sirenians. Rep Int Whal Commn Spec Issue 3

Phleger CF (1998) Buoyancy in marine fishes: direct and indirect role of lipids. Am Zool 38:321-330

Pike GC, MacAskie IB (1969) Marine mammals of British Columbia. Bull Fish Res Board Can 71:1-54

Pitman RL, Ensor P (2003) Three forms of killer whales (Orcinus orca) in Antarctic waters. J Cetacean Res Manag 5:131-139

Pyle P, Schramm MJ, Keiper C, Anderson SD (1999) Predation on a white shark (Carcharodon carcharias) by a killer whale (Orcinus orca) and a possible case of competitive displacement. Mar Mamm Sci 15:563-568

Ramírez-Macías D, Vázquez-Juárez R, Galván-Magaña $F$, Munguía-Vega A (2007) Variations of the mitochondrial

Editorial responsibility: Hans Heinrich Janssen, Oldendorf/Luhe, Germany control region sequence in whale sharks (Rhincodon typus) from the Gulf of California, Mexico. Fish Res 84: $87-95$

> Raschi W, Tabit C (1992) Functional aspects of placoid scales: a review and update. Aust J Mar Freshw Res 43:123-147

Rice DW (1968) Stomach contents and feeding behaviour of killer whales in the eastern North Pacific. Norsk Hvalfangst Tidskr 57:35-38

Sambrook J, Fritsch EF, Maniatis T (1989) Molecular cloning: a laboratory manual. 3rd edn. Cold Spring Harbor, NY

> Saulitis E, Matkin C, Barrett-Lennard L, Heise K, Ellis G (2000) Foraging strategies of sympatric killer whale (Orcinus orca) populations in Prince William Sound, Alaska. Mar Mamm Sci 16:94-109

Schluter D (2001) Ecology and the origin of species. Trends Ecol Evol 16:372-380

Sigler MF, Hulbert LB, Lunsford CR, Thompson NH, Burek K, O'Corry-Crowe G, Hirons AC (2006) Diet of Pacific sleeper shark, a potential Steller sea lion predator, in the northeast Pacific Ocean. J Fish Biol 69:392-405

> Stevens TA, Duffiled DA, Asper ED, Hewlett KG, Bolz A, Gage LJ, Bossart GD (1989) Preliminary findings of restriction fragment differences in mitochondrial DNA among killer whales. Can J Zool 67:2592-2595

> Tamura K, Dudley J, Nei M, Kumar S (2007) MEGA4: Molecular Evolutionary Genetics Analysis (MEGA) software version 4.0. Mol Biol Evol 24:1596-1599

Tollit DJ, Schulze AD, Trites AW, Olesiuk PF, Crockford SJ, Gelatt TS, Ream RR, Miller KM (2009) Development and application of DNA techniques for validating and improving pinniped diet estimates. Ecol Appl 19:889-905

> Visser IN (2005) First observation of feeding on thresher (Alopias vulpinus) and hammerhead (Sphyrna zygaena) sharks by killer whales (Orcinus orca) specialising on elasmobranch prey. Aquat Mamm 31:83-88

> Ward RD, Holmes BH, White WT, Last PR (2008) DNA barcoding Australasian chondrichthyans: results and potential uses in conservation. Mar Freshw Res 59:57-71

Wright BA, Hulbert L (2000) Shark abundance increases in the Gulf of Alaska. PICES Press. Newsl North Pac Mar Sci Organ 8:16-22

Yano K, Dahlheim ME (1995) Behavior of killer whales Orcinus orca during longline fishery interactions in the southeastern Bering Sea and adjacent waters. Fish Sci 61: 584-589

Yano K, Stevens JD, Compagno LJV (2004) A review of the systematics of the sleeper shark genus Somniosus with redescriptions of Somniosus (Somniosus) antarcticus and Somniosus (Rhinoscymnus) longus (Squaliformes: Somniosidae). Ichthyol Res 51:360-373

Submitted: July 22, 2010; Accepted: November 5, 2010

Proofs received from author(s): December 18, 2010 